\title{
A BIDRA TIL ET GODT ARBEIDSMILJØ
}

Når konflikter på arbeidsplassen påvirker trivsel og arbeidsinnsats, kan det føre til sykmeldinger, oppsigelser eller psykiske lidelser. Alle vil gjerne ha et hyggelig arbeidsmiljø og alle har et ansvar for å bidra til dette.

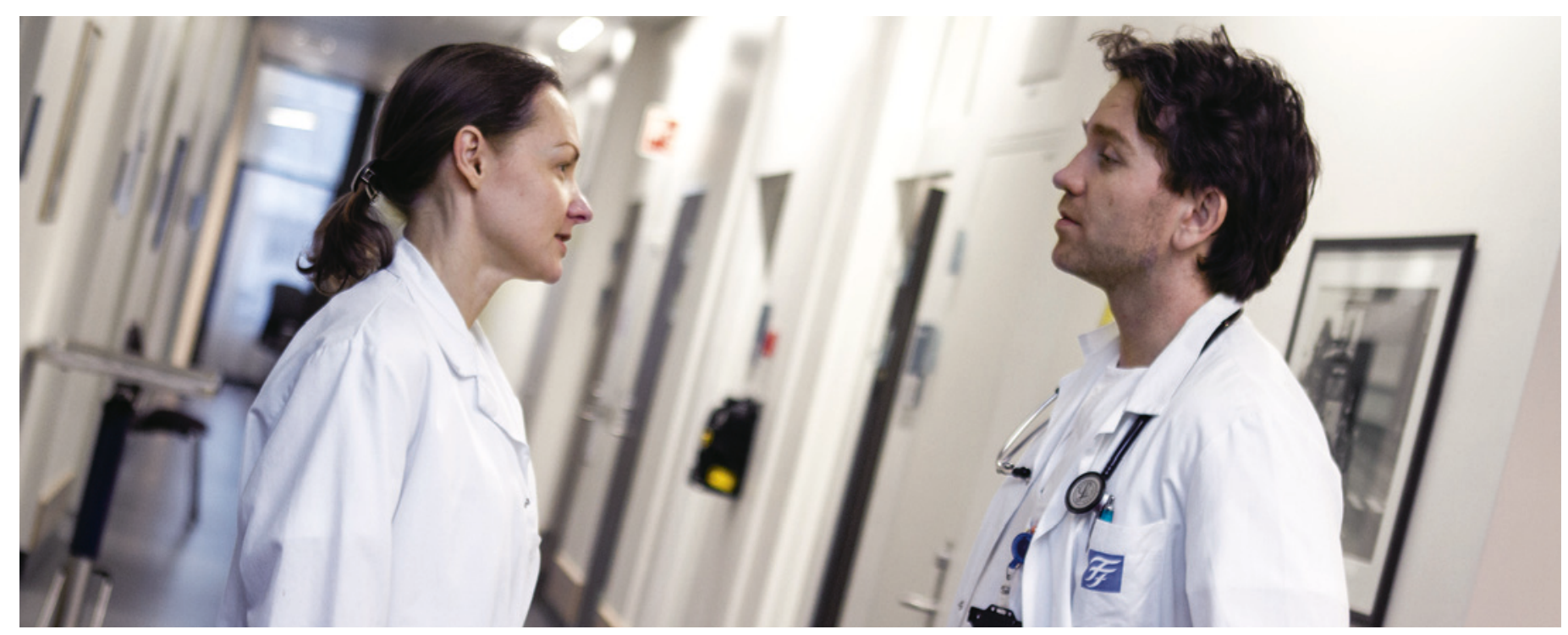

Gode kolleger ved St. Olavs hospital. Foto: Ole Kristian Losvik

Det kan være vanskelig å ta opp konflikter som oppstår og det kan være enda vanskeligere å løse dem. Spesielt kan dette være tilfelle om man ikke er helt trygg på personen man er i konflikt med.

\section{Ansvar for egen trivsel}

Psykolog Jan Andersen har arbeidet med konflikthåndtering på arbeidsplasser siden 1984. Han mener at om noen forsøker å krenke deg på jobb, er det ditt ansvar ikke å la deg krenke.

- Det er to hovedproblemer i arbeidslivet som skaper dårlig arbeidsmiljø: baksnakking og furting. Hvis man klarer å unngå dette, vil man momentant få et bedre arbeidsmiljø, sier Andersen.

Han mener at vi lærer at vi har ansvar for hverandres følelser og ikke våre egne.

- Jeg sier at det er du som provoserer meg når det egentlig er jeg som lar meg provosere. Når vi lar andre bestemme hva vi skal føle, får vi et dårlig liv og lar oss krenke av bagateller, mener Andersen.

\section{Snakk med, ikke om, hverandre}

Psykolog Sara Aarseth underviser i den tette sammenhengen mellom psykisk helse og arbeidsliv. Hun har også jobbet med konflikthåndtering på arbeidsplassen og er enig i at man må snakke sammen når det oppstår konflikter.

- Hvis man blir utsatt for små, hverdagslige brudd og det dermed oppstår en liten konflikt, vil det beste være å ta opp saken med den det gjelder. Den praktiske erfaringen viser likevel at mange synes at dette kan være vanskelig. Mitt generelle råd er da å ta det opp med leder, verneombud eller tillitsvalgt. Slik kan du få hjelp til å løse konflikten, sier Aarseth til Tidsskriftet.

Hun stiller seg undrende til Andersens mening om at det er ens egen skyld om man lar seg krenke av en kollega.

- Det vil selvfølgelig alltid finnes unntak hvor noen er overfølsomme, men det er en grov forenkling å si at konflikter kun handler om dette. Det er stor forskjell på konflikter i arbeidslivet. Hvis man blir utsatt for trakassering eller mobbing har arbeidsgiver en kartleggingsplikt til å finne årsak og komme frem til tiltak, sier Aarseth.

\section{Uvisshet om antall}

- Halvparten av oss vil oppleve å være sykmeldte i løpet av arbeidslivet. Det finnes få store studier på området, og vi vet lite om hvor mange av sykmeldingene som skyldes psykiske lidelser som også er relatert til arbeidskonflikter. I tillegg vet vi for lite om hvilke tiltak som er virksomme, sier Aarseth. Hun mener imidlertid at det stort sett står bra til i norsk arbeidsliv og at de fleste har gode arbeidsplasser.

\section{Elisabeth Jacobsen}

Tidsskriftet

Les hele saken på Legejobber.no
«Det er to hovedproblemer i arbeidslivet som skaper dårlig arbeidsmiljø: baksnakking og furting» 